\title{
Effect of gamma irradiation on sprout inhibition and its physiological mechanism of Chestnuts
}

\author{
Y. UchiYama \\ Okayama Agricultural Experiment Station, Okayama City
}

\begin{abstract}
Summary
From the results of this experiment on the effects of gamma irradiation on the sprout inhibition and its physiological mechanism purporting the exten tion of storage life of chestnuts, the following summary can be made.

Chestnuts harvested in October were irradiated with $1 \times 10^{4}, 5 \times 10^{4}$ roentgen of Co 60 gamma rays, then stored in moist sawdust at room temperature. On February, over 50 percent of nuts which had been received in low doses roentgen showed visible growth of roots, but in the untreated nuts only 30 percent. After that, the roots of untreated nuts had continued vigorous growth, whereas the rooting of the treated nuts with the lower dose were gradually prevented, but not completely stunted. On the other hand, high doses completely inhibited the rooting and sprouting. Most of treated with the nuts with the higher doses were still salable in April. More rotting were found in the treated nuts higher doses than those with the lower doses. Such unfavorable effects tended to increase in the nuts with higher under the elongated storage. From

these observations.: concerning results with beneficial effect of root and sprout inhibition, it is supposed that the range of $3.5 \times 10^{4} 5 \times 10^{4}$ roentgen is the most desirable level of treatments.

Total ascorbic acid contents were slightly diminished in paralell with increasing dose levels and elongation of storage times. Sugar contens showed that the conversion of starch to sugars progressed slightly by the irradiation. Soluble astringent contents did not show any change by the irradiation.

The effects of irradiation on the respiratory activity were obviously recognized, but it seemed that the changes of respiration had not so much direct correlations with mechanism of root and sprout inhibition.

The amylase activities decreased immediately after irradiation but rapid and significant increasing followed just after. No important variations were found in either polyphenoloxidase or peroxidase, though showed a tendency to decrease with small inactivation by irradiation. The correlation between the rotting and the oxidase activity was not clear.
\end{abstract}

\section{Introduction}

Gamma irradiation has recently been reported to be an effective sprouting inhibitor for potatoes and onions ${ }^{(4,10)}$. SPARrow and Christensen ${ }^{(12)}$ reported that the sprouting of potatoes was greatly reduced with a dose of 5,000 rep and completely inhibited at 20,000 rep or higher. Brownell and coworkers ${ }^{(2)}$ indicated that doses from 10,000 to 15,000 rep were minimum that were necessary for complete sprout inhibition of potatoes. On the other hand ${ }^{(7,8,11)}$, it was also observed that the tubers which received comparatively high doses of gamma irradiation increased in the percentage of the loss resulted from rotting during the storage. Generally, the irradiation dose of approximately 10,000 roentgen seems to be preffered by many investigators. Those statements were based on experiment with a number of different vegetables, not including chestnuts.

The only report on the application of gamma irradiation for sprout inhibiting of chestnuts is that of $\mathrm{T}$. Iwata and $\mathrm{K}$. OGata ${ }^{(9)}$. They conducted some observations on Imakita and Ginyose varieties immediately after treatment with 0, 15,000, 30,000 and 60,000 roentgen, and after various intervals during the storage. They reported that almost complete inhibiting effects were obtained with all the doses used regardless of varieties, and that no significant

Received for publication August 2, 1966 
differences were indicated in the chemical constituents between the irradiated and the unirradiated chestnuts.

Preliminary experiments at this station gave the same indications with these effects among the higher doses, whereas the increased effects on the sprouting and rooting were observed in the early growing stage of chestnut at the lower doses, though storage temperature and irradiation doses were somewhat different from those on the work of Iwata and Ogata.

This work was carried out at this station for a period of six months to determine whether this method has any potential usefullness for the storage of chestnuts. Besides the effects on sprouting and rotting has been also investigated, including determination of chemical constituents and activities of some enzymes such as amylases, polyphenoloxidase and peroxidase.

\section{Materials and Methods}

The nuts of Castanea crenata cultivar, Tsukuba were harvested in the orchard located at Osa, Okayama Prefecture in October and stored in most sawdust at room temperature.

A 1,800-curie Co 60 with a dose rate of about 41 roentgen/min. to a $225 \mathrm{sq}$. cm surface was adapted for continuous operation during off-clinical hours at the faculty of medicine, Okayama university. In each dose 60 nuts were arranged in the tray and set in frame to be kept in fixed positions. The top of the upper layer of nuts was $75 \mathrm{~cm}$ below the radiation source. Doses were $10,000,20,000,35,000$ and 50,000 roentgen, with respective dwell times in the irradiator of $4,8,15$ and 20 hours. After the desired dose levels had been obtained, the portions of the treated and untreated samples were taken to the laboratory for analysis, and the remaining samples were stored in moist sawdust at room temperature.

Nuts were examined at regular intervals for observable changes in the appearance of rooting, sprouting and rotting. The occurred symptoms were expressed as percent.

Ascorbic acid was determined by a modification of the 2.4-dinitrophenylhydrazine procedure as described by $\mathrm{T}$. TAKAhashi and $\mathrm{K}$. $\mathrm{KoNO}^{(15)}$. Aliquots of extracted solution with meta phosphoric acid was used for direct determination of dehydro ascorbic acid (DA). Another aliquot was used for determination of total ascorbic acid (TA). Reduced ascorbic acid (AA) was measured by the difference between DA and TA. Results were show in terms of DA, $\mathrm{TA}$ and $\mathrm{AA}$.

Reducing and total sugar contents were determined by Somogyi's method with some modifications.

Soluble tannin as astringent materials was determined by the titration method of potassium permanganate. Aliquots of extracted solution with water were used for its determination.

Carbon dioxide evolution was measured as follows: nuts were placed in desicator, and the carbon dioxide given off from nuts was collected in $25 \mathrm{ml}$ of $2 \mathrm{~N}$ potassium hydroxide solution placed at the bottom of desicator, and was filled up to $250 \mathrm{~m} l$ with water adding $10 \mathrm{~m} l$ of 25 percent barrium chloride solution, then titrated with $0.2 \mathrm{~N}$ hydrochloric acid solution.

Estimasion of amylase activity was as follows: the peeled nuts were carefully cut and chopped with stainless knife, then $5 \mathrm{~g}$ of tissues were weighed and homogenized at high speed

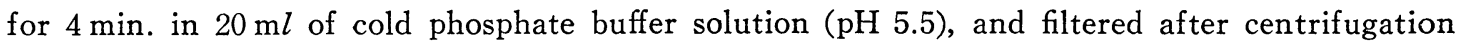
at $4,000 \mathrm{rpm}$ for $5 \mathrm{~min}$. Appropriate filtrate from the homogenates were immediately assayed 
for the activity of amylase by the method of Ostwald viscosimeter, that is, $2 \mathrm{ml}$, of filtrate (as crude enzyme solution) was added to $10 \mathrm{~m} l$ of 1 percent starch solution previouly prepared to $\mathrm{pH} 5.5$ with phosphate buffer solution and held at $37.5^{\circ} \mathrm{C}$. When the mixture was kept at $37.5^{\circ} \mathrm{C}$, viscosity changes were measured at the given intervals in the reaction of $0,5,10,15$, 20 and $30 \mathrm{~min}$. Exactly $30 \mathrm{~min}$. after, the mixture was quickly alkalified by the addition of Somogyi's reagent, and liberated reducing sugar was determined from the residual iodoine which was titrated with standard thiosulfate solution. Reducing power of amylase was expressed in term of monomolecular reaction rate constant $K$, which was calculated by the use of the following equation:

$$
K=1 / t \cdot \log a / a-x
$$

where

$$
\begin{aligned}
& \text { K.........Monomolecular reaction rate constant } \\
& t \text {.........Reaction time (30 min.) } \\
& \text { a .........Amount of starch, which hypothesized as } 75 \text { percent of } a \text { given substrate (mg) } \\
& x \text {..........Liberated reducing sugar as maltose (mg) }
\end{aligned}
$$

On the other hand, the percentage of degradation of substrate was calculated basing on the result of viscosity. Such resulting value was represented by the following equation:

$$
D=\eta_{\mathrm{sp}}-\eta_{\mathrm{sp}}^{\prime} / \eta_{\mathrm{sp}}-1 \times 100
$$

where

$D$.........Percent of degradation of substrate

$\eta_{\mathrm{sp}}$.......Relative viscosity at zero hour

$\eta_{\text {sp }}^{\prime}$.......Relative viscosity at each definite time

Estimation of peroxidase activity was as follows : $10 \mathrm{~g}$ of peeled and chopped tissues were weighed, and homogenized in $10 \mathrm{~m} l$ of cold phosphate buffer solution ( $\mathrm{pH} \mathrm{6.0),} \mathrm{then} \mathrm{centrifuged}$ and filtered as well as for the assay of amylase. The filtered extract was frozen immediately and stored at $-15^{\circ} \mathrm{C}$ until analysis was made. The filtrate was assayed for enzyme activity by method of Warburg manometry ${ }^{(1)}$ at $20^{\circ} \mathrm{C}$. The samples were removed from frozen storage and $0.1 \mathrm{ml}$ of defrosted solution, as crude peroxidase solution, was placed in the side arm. The substrate (contained $0.2 \mathrm{~m} l$ of 5 percent pyrogallol, $0.5 \mathrm{~m} l$ of phosphate buffer ( $\mathrm{pH} 6.0$ ) and $1.5 \mathrm{ml}$ of $0.01 \mathrm{M}$ hydrogen peroxide solution) was placed in the main compartment. The gas phase in the manometer was air, and they were equilibrated at $20^{\circ} \mathrm{C}$ for $10 \sim 20 \mathrm{~min}$., then the content of side arm was mixed with the solution of the substrate in the main compartment. Reading was taken at $3,5,6,10$ and $30 \mathrm{~min}$. after mixing and recorded. The results of measurement of the enzyme activities were expressed as carbon dioxide $\mathrm{ml} / \mathrm{g} / \mathrm{hr}$.

Estimation of polyphenoloxidase activity(1) was as follows: for the assay, the enzyme solution was prepared as well as peroxidase, but the provided phosphate buffer solution to extract was $\mathrm{pH}$ 7.3. The rate of oxygen uptake on the ezyme activity was meastred with Warburg manometer. The side arm contained $1 \mathrm{~m} l$ of enzyme solution. The main compartment contained $2 \mathrm{~m} l$ of $0.03 \mathrm{M}$ phosphate buffer solution, which was previously prepared to $\mathrm{pH} 7.3$ and was $10 \mathrm{mg}$ of cathecol added. A strip of whatman No. 40 filter paper and $0.2 \mathrm{~m} l$ of $2 \mathrm{~N}$ potassium hydroxide solution were placed in the center well of each flask. The gas phase in the manometer was air. After equilibrated at $25^{\circ} \mathrm{C}$ for a time the measurement was carried out. Reading was taken as well as proxidase and results were expressed as $\mathrm{O}_{2}{ }^{\mu} l / \mathrm{g} / \mathrm{hr}$. 


\section{Results and Discussion}

\section{Rooting, Sprouting and Rotting}

The sprouting of chestnut begins with the break up of its husk at the upper end, then the root come out. When the root grows to a considerable length (about $20 \sim 30 \mathrm{~mm}$ ), the sprout appears. The results on rooting, sprouting and rotting of chestnuts after irradiation are summerized in Table 1.

No significant effects on the quality of nuts up to the December 14 were observed. On January 15, untreated and treated nuts with $1 \times 10^{4}$ and $2 \times 10^{4}$ roentgen slightly rooted. On February 15, over 50 percent of treated nuts with the lower doses (at the doses of $1 \times 10^{4}$ and $2 \times 10^{4}$ roentgen) showed visible length of roots, but only 30 percent of the untreated nuts. Such effect of irradiation (in case of lower doses) which appear to be stimulative at early stage of rooting may suggest that this lower doses would activate the physiological mechanisms of the chestnuts, and as a result, the nutritious condition was effectively utilized causing the rapid growth. The increased amylase activity was recognized in the irradiated nuts, especially lower irradiated nuts (this fact will be discussed in later section). Therefore, it may be considered that there exist a relationship between the promoting effect of sprouting and the increased amylase activity. However, the accelerated growth was only temporal, and did not last long. During the storage, the growth of rooting was gradually prevented and fairly stunted. On the other hand, vigorous rooting in the untreated nuts was continuted. On

Table 1. Effects of gamma irradiation on rooting, sprouting and rotting of chestnuts (Tsukuba).

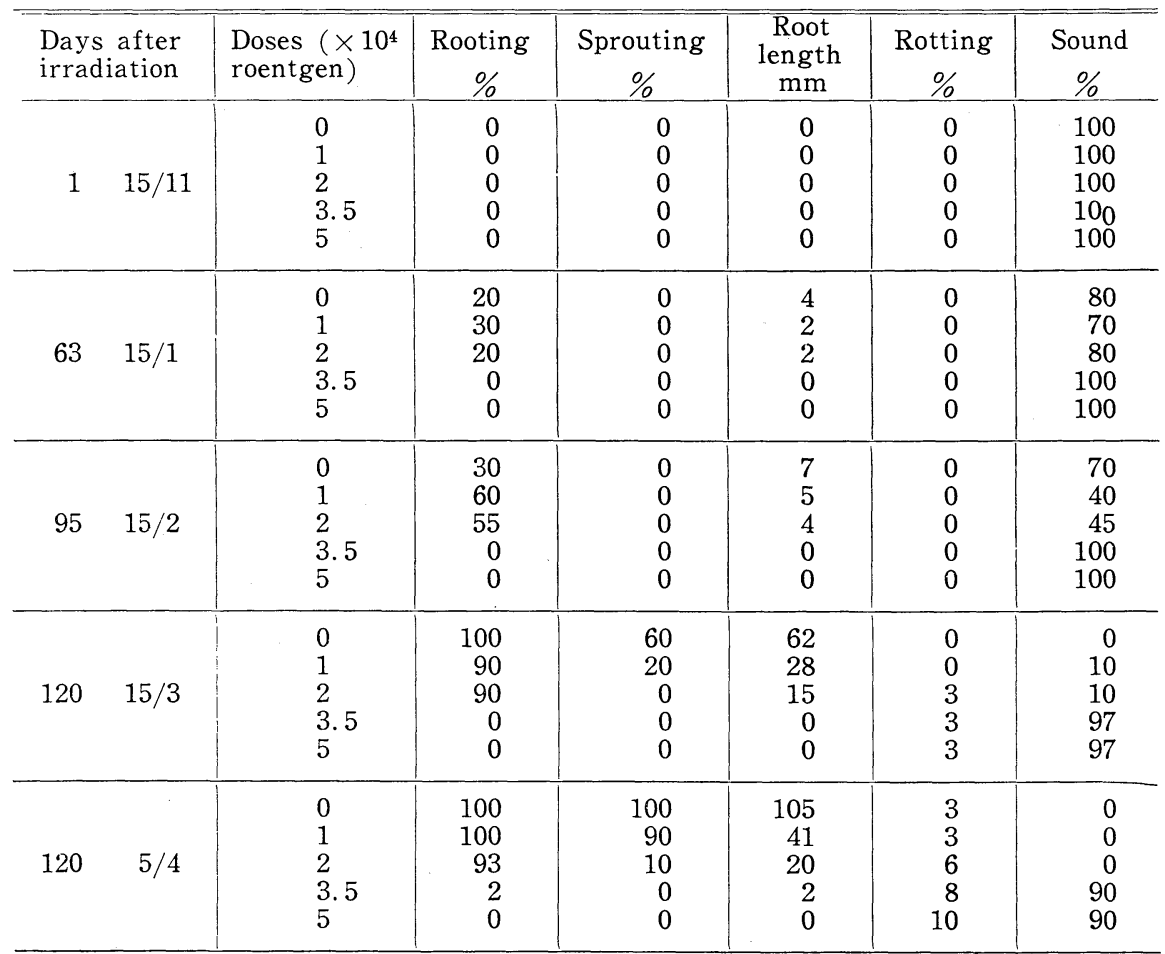


March 15, the untreated and treated nuts with the lower doses almost rooted, while most of the treated nuts with the higher doses were still salable. From these results, the lower limit of irradiation for inhibition of rooting seemed to be about $3.5 \times 10^{4}$ roentgen. More rotting was found in the treated nuts with the higher doses than those treated with the lower doses. Such unfavorable effects on the treated nuts increased as the storage time elongated, moreover the affected nuts were putrefied with fungal developments at last. It has been often reported that rot incidence in the potato tubers occured when they received relatively high dose of gamma irradiation. IwATA and $\mathrm{OGATA}^{(9)}$ indicated that the gamma rays-treated chestnuts also seemed to become susceptible to storage rotting. From these observations, concerning results with the beneficial effect of rooting inhibition it is supposed that from $3.5 \times 10^{4}$ to $5 \times 10^{4}$ roentgen is the most desirable level of treatment.

\section{Chemical Components}

Analytical results are shown in Table 2.

Ascorbic acid: Total ascorbic acid (TA) contents in the treated nuts were slightly lower than the untreated, which the concentration diminishing with increasing dose levels. A slight but consistent decrease in ascorbic acid during the storage were observed as in many other fruits ${ }^{(5,13)}$.

Sugar: Sugar contents are also included in Table 2. There is the suggestion that the conversion of starch to sugar progressed slightly in the lots given each roentgen. BROwNELL ${ }^{(3)}$ reported that the initial decreases and the following rapid increases in sugar contents of potatoes were observed after irradiation. In this work, there were only slight increases in

Table 2. Effects of gamma irradiation on chemical components of chestnuts.

\begin{tabular}{|c|c|c|c|c|c|c|c|c|}
\hline \multicolumn{2}{|c|}{$\begin{array}{l}\text { Days after } \\
\text { irradiation }\end{array}$} & \multirow{2}{*}{$\begin{array}{c}\begin{array}{c}\text { Doses }\left(\times 10^{4}\right. \\
\text { roentgen })\end{array} \\
0 \\
1 \\
2 \\
3.5 \\
5\end{array}$} & \multirow{2}{*}{$\begin{array}{c}\begin{array}{c}\text { Ascorbic } \\
\text { TA }\end{array} \\
18.14 \\
17.58 \\
16.95 \\
16.69 \\
16.54\end{array}$} & \multirow{2}{*}{$\begin{array}{l}\text { acid } \\
\text { DA } \\
9.17 \\
9.12 \\
9.38 \\
9.28 \\
9.47\end{array}$} & \multirow{2}{*}{$\begin{array}{l}\mathrm{mg} \% \\
\text { AA } \\
8.97 \\
8.46 \\
7.57 \\
7.41 \\
7.07\end{array}$} & \multirow{2}{*}{$\begin{array}{c}\text { Total } \\
\text { sugar } \\
\%\end{array}$} & \multirow{2}{*}{\begin{tabular}{|c|}
$\begin{array}{c}\text { Reducing } \\
\text { sugar } \\
\%\end{array}$ \\
1.17 \\
1.20 \\
1.22 \\
1.32 \\
1.47 \\
\end{tabular}} & \multirow{2}{*}{$\begin{array}{c}\begin{array}{c}\text { Tannin as } \\
\text { astringents } \\
\text { (all nuts) }\end{array} \\
0.36 \\
0.41 \\
0.40 \\
0.39 \\
0.36\end{array}$} \\
\hline 1 & $15 / 11$ & & & & & & & \\
\hline 63 & $15 / 1$ & $\begin{array}{l}0 \\
1 \\
2 \\
3.5 \\
5\end{array}$ & $\begin{array}{l}16.61 \\
16.39 \\
16.00 \\
15.94 \\
15.33\end{array}$ & $\begin{array}{l}10.93 \\
10.87 \\
10.98 \\
11.00 \\
11.10\end{array}$ & $\begin{array}{l}5.68 \\
5.52 \\
5.02 \\
4.94 \\
4.23\end{array}$ & $\begin{array}{l}9.10 \\
8.86 \\
8.74 \\
8.59 \\
7.26\end{array}$ & $\begin{array}{l}1.41 \\
1.27 \\
1.33 \\
1.22 \\
1.10\end{array}$ & $\begin{array}{l}0.32 \\
0.38 \\
0.46 \\
0.35 \\
0.35\end{array}$ \\
\hline 93 & $15 / 2$ & $\begin{array}{l}0 \\
1 \\
2 \\
3.5 \\
5\end{array}$ & $\begin{array}{l}16.84 \\
16.09 \\
15.93 \\
15.77 \\
15.84\end{array}$ & $\begin{array}{l}11.41 \\
11.64 \\
11.57 \\
11.98 \\
11.71\end{array}$ & $\begin{array}{l}5.43 \\
4.45 \\
4.36 \\
3.79 \\
4.13\end{array}$ & $\begin{array}{l}8.72 \\
8.46 \\
8.87 \\
8.68 \\
8.38\end{array}$ & $\begin{array}{l}1.55 \\
2.09 \\
1.66 \\
1.23 \\
1.29\end{array}$ & $\begin{array}{l}0.43 \\
0.40 \\
0.38 \\
0.46 \\
0.43\end{array}$ \\
\hline 120 & $15 / 3$ & $\begin{array}{l}0 \\
1 \\
2 \\
3.5 \\
5\end{array}$ & $\begin{array}{l}15.96 \\
16.08 \\
15.73 \\
15.55 \\
15.73\end{array}$ & $\begin{array}{l}11.70 \\
12.17 \\
12.40 \\
12.50 \\
12.67\end{array}$ & $\begin{array}{l}4.26 \\
3.91 \\
3.33 \\
3.05 \\
3.06\end{array}$ & $\begin{array}{l}6.45 \\
7.55 \\
7.24 \\
8.75 \\
7.32\end{array}$ & $\begin{array}{l}1.31 \\
1.09 \\
1.10 \\
1.65 \\
1.30\end{array}$ & $\begin{array}{l}0.34 \\
0.33 \\
0.36 \\
0.38 \\
0.46\end{array}$ \\
\hline 140 & $5 / 4$ & $\begin{array}{l}0 \\
1 \\
2 \\
3.5 \\
5\end{array}$ & $\begin{array}{l}15.21 \\
15.17 \\
15.03 \\
15.06 \\
14.73\end{array}$ & $\begin{array}{l}12.34 \\
12.14 \\
12.81 \\
12.74 \\
12.61\end{array}$ & $\begin{array}{l}2.87 \\
3.03 \\
2.22 \\
2.32 \\
2.12\end{array}$ & $\begin{array}{l}6.14 \\
6.66 \\
7.24 \\
7.10 \\
7.33\end{array}$ & $\begin{array}{l}1.21 \\
1.08 \\
1.03 \\
1.27 \\
1.27\end{array}$ & $\begin{array}{l}0.41 \\
0.44 \\
0.44 \\
0.45 \\
0.48\end{array}$ \\
\hline
\end{tabular}


sugar contents among the treated nuts, however, not any decreases until about 60 days after irradiation. The respiration of nuts markedly increased either immediately or shortly after irradiation (this fact will be discussed in later section). However, the behavior of sugar which seems to be utilized as the source of energy for the respiration, and as a result, causing the decrease of sugar content is not clear from this results.

Soluble tannin as astringent contents: There were no significant effects of irradiation on the soluble astringent contents as shown in Table 2 .

\section{Respiration}

The effects of irradiation on the carbon dioxide evolution of chestnuts are shown in Fig. 1.

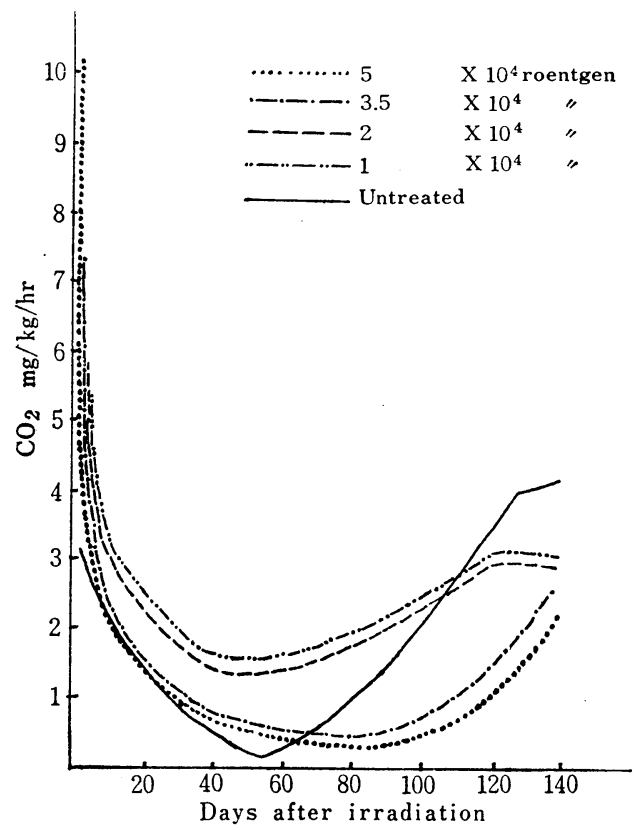

Fig. 1. Effects of gamma irradiation on the carbon dioxide evolution. As indicated in Fig. 1, nuts irradiated had a marked increase in carbon dioxide evolution immediately after the treatment. The stimurative effect of irradiation were increased with increasing doses, that is, the carbon dioxide evolution of nuts which had been treated at $5 \times 10^{4}, 3.5 \times 10^{4}, 2 \times 10^{4}$ and $1 \times 10^{4}$ roentgen was about each $3.2,2.3,2.0$ and 1.5 times greater than that of the untreated. On the day succeeding the treatment, however, these increased curves rapidly lowered as low as that of the untreated about tow weeks after irradiation. In April, untreated and treated nuts with the lower doses showed again the considerable increasing curves, but nuts with the higher doses were slight in chang. The effects of irradiation on the respiratory activity which seems to be physiologically important behaviour of chestnuts were obyiously recognizable, but it seemed that the changes of respiration had not so much correlation with the mechanism of root inhibition directly. The untreated group and the lower irradiated nuts reactivated their respiration approximately after 60 days and followed by sprouting. On the other hand, the higher irradiated nuts did not any sprout in spite of their increased respiration during storage.

\section{Enzyme Activities}

Amylase: The effects of irradiation on amylase activities in the given nuts were measured by fall of viscosity or by estimating some new reducing groups formed during the course of the reaction. Table 3 gives the degradation rate of starch by the viscosity. Table 4 gives the variances in the values of amylase activities by reducing power. The discrepancy between the changes in viscosity and in reducing power undergoing hydrolysis by amylase seems to indicate the pattern of enzyme action to the glycosidic linkage in the starch macromolecule. The results given in Table 3 indicates that the major degradation occurred very early in the reaction. As indicated in Table 3 the values of viscosity changes are very sensitive indication of even traces of amylase activities. Fig. 2 shows a comparison of the rate of degradation on 
Table 3. Effects of gamma irradiation on amylase activities : Rate of degradation of starch (on the occasion of viscosity).

\begin{tabular}{c|r|c|c|c|c|c}
\hline \hline \multirow{2}{*}{$\begin{array}{c}\text { Doses }\left(\times 10^{4}\right. \\
\text { roentgen })\end{array}$} & \multirow{2}{*}{$\begin{array}{c}\text { Time of } \\
\text { reaction min. }\end{array}$} & \multicolumn{5}{|c}{ Days after irradiation (Date) } \\
\cline { 3 - 7 } & & $\begin{array}{c}1 \\
(15 / 11)\end{array}$ & $\begin{array}{c}63 \\
(15 / 1)\end{array}$ & $\begin{array}{c}93 \\
(15 / 2)\end{array}$ & $\begin{array}{c}120 \\
(15 / 3)\end{array}$ & $(5 / 4)$ \\
\hline \multirow{2}{*}{0} & 5 & 32.939 & 34.433 & 45.489 & 48.625 & 49.000 \\
& 30 & 75.740 & 79.175 & 87.594 & 93.359 & 31.571 \\
1 & 5 & 37.014 & 65.055 & 68.085 & 69.750 & 57.053 \\
& 30 & 50.096 & 92.913 & 85.461 & 39.750 & 74.526 \\
2 & 5 & 39.510 & 69.231 & 74.436 & 75.748 & 53.468 \\
& 30 & 62.610 & 91.346 & 94.737 & 92.027 & 61.850 \\
3.5 & 5 & 15.931 & 64.235 & 61.495 & 55.432 & 45.416 \\
& 30 & 55.278 & 86.007 & 34.890 & 97.342 & 69.252 \\
5 & 5 & 14.384 & 63.165 & 58.941 & 53.748 & 41.679 \\
& 30 & 33.790 & 88.722 & 80.588 & 92.027 & 48.560 \\
\hline
\end{tabular}

Table 4. Effects of gamma irradiation on amylase activities : Monomolecular reaction rate constant (on the occasion of reducing power)

\begin{tabular}{c|c|c|c|c|c}
\hline \hline \multirow{2}{*}{$\begin{array}{c}\text { Doses }\left(\times 10^{4}\right. \\
\text { roentgen) }\end{array}$} & \multicolumn{5}{|c}{ Days after irradiation (Date) } \\
\cline { 2 - 6 } & $\begin{array}{c}1 \\
(15 / 11)\end{array}$ & $\begin{array}{c}63 \\
(15 / 1)\end{array}$ & $\begin{array}{c}93 \\
(15 / 2)\end{array}$ & $\begin{array}{c}120 \\
(15 / 3)\end{array}$ & $\begin{array}{c}140 \\
(15 / 4)\end{array}$ \\
\hline 0 & 0.00664 & 0.00382 & 0.00392 & 0.00657 & 0.00657 \\
1 & 0.00453 & 0.00392 & 0.00532 & 0.00798 & 0.00839 \\
2 & 0.00417 & 0.00575 & 0.00564 & 0.00726 & 0.00867 \\
3.5 & 0.00449 & 0.00938 & 0.00564 & 0.00275 & 0.00746 \\
5 & 0.00216 & 0.00765 & 0.00795 & 0.00327 & 0.00891 \\
\hline
\end{tabular}

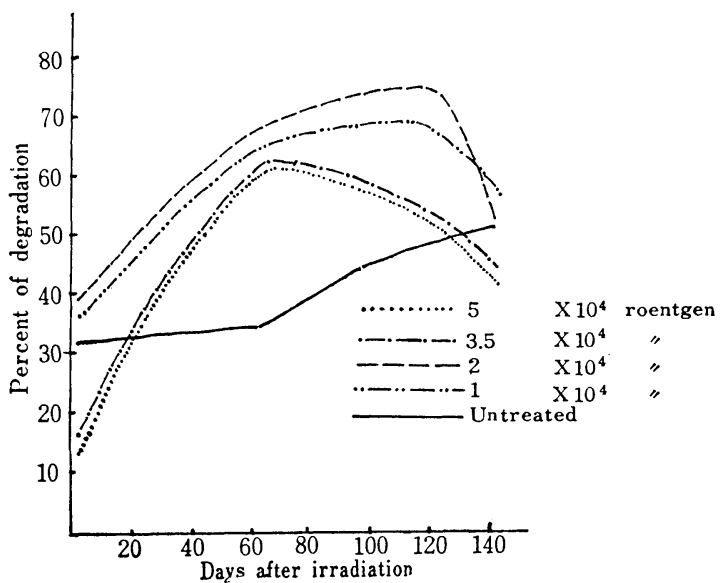

Fig. 2. Effects of gamma irradiation on amylase activities (on the occasion of viscosity).

the occasion of viscosity changes at $5 \mathrm{~min}$. in the reaction. The values of reducing power presented in Table 4 shows the narrower range of values compared to those show in Table 3 and Fig. 2. Therefore, this differences in the values of hydrolysis of starch which basing on these two changes in reducing power and viscosity seems to suggest that the manner of hydrolysis by amylase goes through changes rapidly from macromolecule to relatively larger molecule and then follows slowly and gradually to the smaller molecule (reducing groups: maltose). Such manner in the amylase reaction were recognized in the treated nuts, especially in the lower irradiated. The change of reducing and viscosity by amylase in the untreated nuts were observed with the values that seems to proportionate to each other.

There appear to be important variations in the amylase activities (Fig. 2) with irradiation. The activities decreased immediately after irradiation, but rapid and significant increasing followed just after. In December, the treated nuts with the higher doses showed again the 


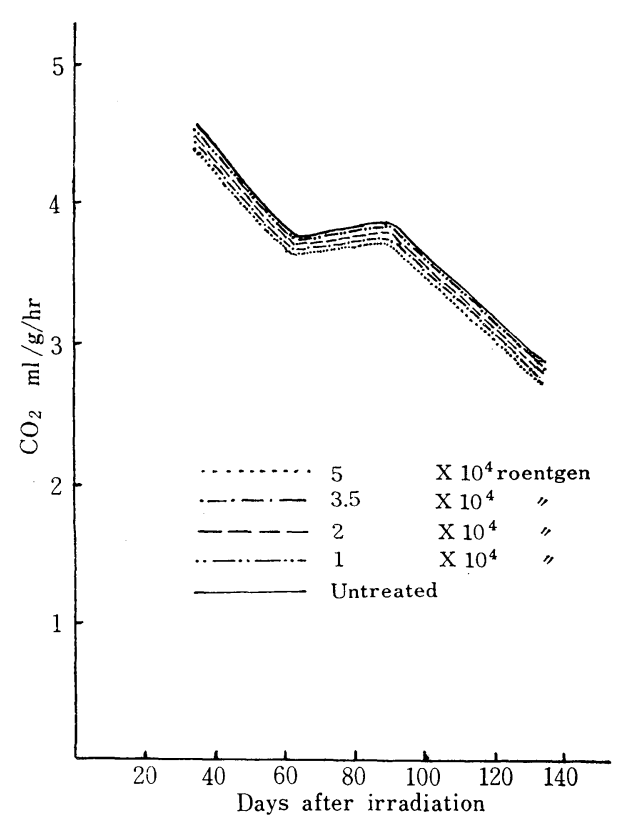

Fig. 3. Effects of gamma irradiation on the peroxidase activities.

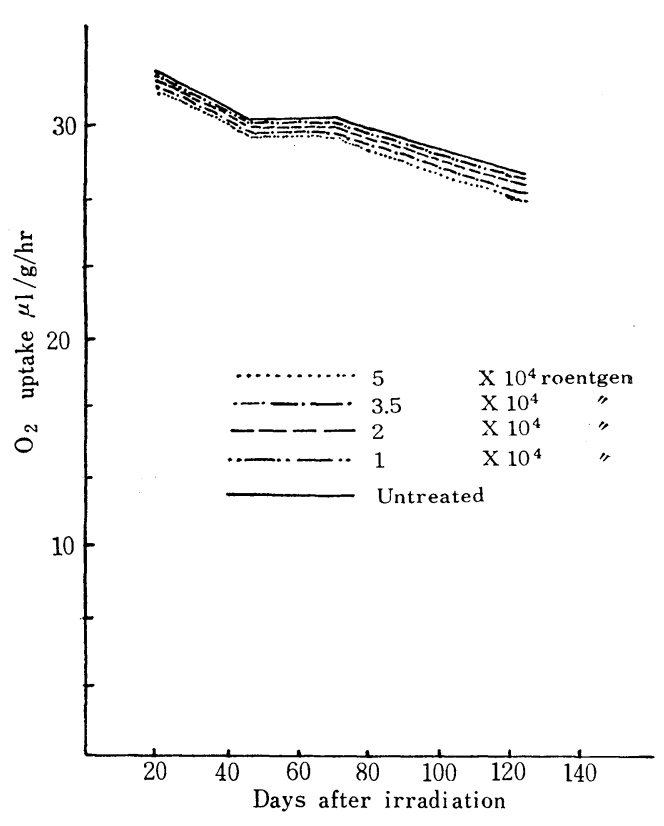

Fig. 4. Effects of gamma irradiation on the polyphenoloxidase activities.

considerable decreases in the activity, but the treated with the lower doses in March. The activity of the untreated nuts continued gradually to increase in during storage. From above results, gamma irradiation on amylase proved to cause inactivation by its direct action immediately after treatment and by indirect action during the storage. However, it is not clear whether increased tendency observed during the storage is caused by the stimulative effect of gamma radiation or by some formation of substrates which become more reactionable to enzyme actions, or both. As protein ${ }^{(2,14)}$ is known to be very sensitive to irradiation, most of enzymes are also oxidized to be inhibited their activities by irradiation. Many investigators ${ }^{(6,14)}$ have reported in recent years concerning the inactivation of enzimes by irradiation which could decrease by the addition of various compound to the enzyme solution. It is assumed that some chemical compounds which shold be protected to amylase activities were contained. in this nuts, though such effects of protection were temporary.

Oxidase: Polyphenoloxidase is known to catalyze the aerobic oxidation of various naturally occuring $o$-dihydroxyphenols to the corresponding o-quinones. Peroxidase, furthermore, can catalyze the oxidation of certain polyphenols in the presence of organic peroxide (or $o$-quinone) to form dark colored polymers. The author of the present study had originally expected a significant correlation between blackening or rotting of chestnuts and oxidase activity, moreover these reactings may be also correlative with mechanism of nuts sprouting, but could not find a distinct relations between them. Fig. 3 and Fig. 4 shows the oxidase activities. The curves shown in these Figs. indicate that the oxidase enzyme conditions were not greatly affected by the irradiation under the given doses. Polyphenoloxidase and peroxidase activities tended to decrease slightly with small inactivation by the irradiation. 


\section{Aknowledgment}

The author wish to express his sincer thanks to Mr. Y. Hayashi, Head of the Station, and Mr. H. Yunomura, for their advices. Thanks are also due to Dr. M. Yamamoto, Prof. of Okayama University, for the use of Co 60 gamma irradiation facility.

\section{Literatures Cited}

1. AKABORI, S. 1956. Research methods of en zyme (in Japanese). Asakura Book Co. 2 : $337-359$.

2. BARRON, E. S. G., S. R, DickMAN., T.P. Singer., and J.A.MUnTz., 1954. Biological effects of external $\mathrm{X}$ and gamma radiation. Mc-Graw Hill Book Co.

3. BROWNell, L. E., C.H. Burn, , and P. G. GustaFSON, 1956. Storage properties of gamma irradiated potatoes. Food Tech. $10: 33$.

4. Brownell, L. E., L. C. ANderson., H. J., CoMBERG, L. L. KeMPE., J. J. MARTIN., J. V. NEHEMIAS., and R. A. Wolf., 1954. Utilization of the goss fission products. Uni. Mich., Eng. Res. Inst. Prog. Rpt. No. 7 : 64, 84. 102.

5. Claudia, E. W., A. T. Doris. ahd C. M. DudLEY, 1963. Ascorbic Acid Retention and color of strawberries as related to low-level irradiation and storage time. Food Tech. $17: 77$.

6. DALE, W. M. 1956. Radiation Biology. McGraw Hill Book Co.

7. DAllin, S. L. and R. L. SAwYeR,. 1959. Effect of gamma and fast electron irradiation on storage qualities of onions. Proc. Amer. Soc. Hort. Sci. 73 : 390-397.

8. 1959. Effect of sprout inhibitions levels of gamma irradiation on the quality of onions. Pro. Amer. Soc. Hort. Sci. 73 : 398
-406 .

9. IwatA, T. and K. OgAtA, 1961. Studies in the storage of chestnuts treated gamma radiation. Bull. Inst. Chem. Res., Kyoto Uni. 39 : 112.

10. OGATA, K., T. IwATA.. and K. Chachin.. 1959. The effect of gamma radiation on sprout prevention and its physiological mechanism in the potato tubers and the onion bulb. Bull. Inst. Chem . Res., Kyoto Univ. $37: 425$.

11. SChreiber, J. S. and M. E. Highland.. 1958. A study of the bio chemistry of irradiated potatoes stored under commercial conditions. Food Res. $23: 464-472$.

12. SPARROW, A.H. and E. Christensen,. 1954. Inproved storage of potato tubers after exposure to ${ }^{60} \mathrm{Co} 60$ gammas. Nucleonics. $12: 16$.

13. Salunkhe. D. K., R. K. Gerber.. and L. H. Pollard,. 1959. Physiological and chmical effects of gamma radiation on certain fruits, vegetables and their products. Pro. Amer. Soc. Hor. Sci. $74: 423$.

14. TANAKA, S., H. HATANO,. S. GANNO, and T. OKAMOUO, 1959. Actions of gamma radiation on enzymes and enzyme systems. Bull. Inst. Chem. Res., Kyoto Univ. $37: 374$.

15. TAKAHASHI, T. and K. KONO, 1954. Vitamin (in Japanese). Shibata Book Co.

クリの発芽抑制と生理機構に及ぼすガンマー線の影響

内 山 善雄

（岡山県立農業試験場）

\section{摘}

クリ（品種：筑波）の貯蔵期間を延長するため, 収穫 後のクリにCo 60- $\gamma$ 線を照射し, 線量と発芽抑制, 貯 藏性の関係を検討した。

なお， $2 ， 3$ の化学成分, 酵素活性の消長をあわせて 検討した。

その結果は次のとおりである。

1. 低線量 $(10,000 \sim 20,000 \gamma)$ は一時的に発芽現象 を促進したが続いて生育する根に生理障害を与えた。

2. 高線量 $(35,000 \sim 50,000$ r $)$ は完全に発芽抑制し た。貯蔵 6 か月後（11月〜4月）な和健全であつた。

\section{要}

3. 貯蔵末期に腐敗, 黑变果が線量に比例して多発し つた。

4. 照射はアミラーゼ活性に特異的な影響を与穴，ま たオキ.シダーゼ，(パーオキシダーゼ，ポリフェノール オキシダーゼ）にわずかな活性低下を及ぼした。

5. 呼吸は照射により急激に上昇したが，日数の経過 とともに次第に正常にか方る傾向を示した。

6. 照射はアスコルビン酸と糖の含量にわずかな変化 を及ぼしたが，タンニン含量には影響を与えなかつた。 